\title{
Tapping of Root Non-Rhizobial Endophytic Bacteria from Chickpea Plant Tissues for Multifunctional Traits
}

\author{
Deepika Chhabra $^{1^{*}}$ and Poonam Sharma ${ }^{2}$ \\ ${ }^{1}$ Department of Microbiology, Punjab Agricultural University, Ludhiana-114004, \\ Punjab, India \\ ${ }^{2}$ Department of Plant Breeding and Genetics, Punjab Agricultural University, \\ Ludhiana-114004, Punjab, India \\ *Corresponding author
}

\section{A B S T R A C T}

\section{Keywords}

Chickpea,

Endophytes, Non rhizobial

Article Info

Accepted:

22 January 2019

Available Online:

10 February 2019

\begin{abstract}
In the present investigation total 167 non rhizobial endophytic bacterial isolates from roots of chickpea were collected and screened for qualitative P solubilization. Out of these 37 potential bacterial endophytic isolates from root were selected for further quantitative Psolubilization, Indole acetic acid (IAA), Gibberelic acid and ACC deaminase production. High P-solubilization was recorded in isolate RBR20 $\left(20.60 \mathrm{mg}_{100 \mathrm{ml}^{1}}\right)$. Maximum amount of IAA was produced by isolate LCRE $9\left(39.60 \mu \mathrm{gml}^{-1}\right)$ (presence of tryptophan) and RBR164 (19.93 $\mu_{\mathrm{gml}}{ }^{-1}$ ) (absence of tryptophan). High amount of GA production was observed in RBR19, RBR127, RBR136 and RBR164 (112.15 $\left.\mu \mathrm{gml}^{-1}\right)$. RBR164 isolate showed highest growth in DF medium with ACC (0.9985). There is need to exploit non rhizobial endophytic bacteria with plant growth promoting traits (PGP) as single or consortium biofertilizer for sustainable agriculture.
\end{abstract}

\section{Introduction}

Non rhizobial endophytic bacteria were characterized from different plant species in last couple of years have raised their prospects to be used as biofertilizer (Akhtar and Siddiqui 2009). Endophytic bacteria are defined as interior colonizers of the plant viz. root, seed, stem and leaf without showing any harmful impact on host plant. Endophytic microorganism can promote plant growth, accelerate seed emergence with enhanced plant establishment under stressful conditions in legume and non-legume plants to amass nutrients by different processes viz. phosphate solubilization (Wakelin et al., 2004), iron chelation (Ryan 2008), preventing disease via antifungal and outcompeting pathogens for nutrients with siderophore production and better plant general resistance.

Endophytic plant growth promoting bacteria produces phytohormones, volatile compounds and co factors such as pyrroquinoline quinine (PQQ), that stimulate growth of plant). Endophytic bacteria directly contribute to the growth of host plant by growth regulator production like auxins, gibberellins and cytokinins (Bhattacharyya and Jha 2012). Several plant associated bacteria are shown to 
supply auxins, indole-3-acetic acid (IAA), which boosts lateral root formation and therefore, nutrient uptake and root exudation by plants. Endophytic bacteria with $\mathrm{P}$ solubilization activity (PSBs) embrace Bacillus megaterium, B. circulans, B. subtilis, genus Pseudomonas straita, $P$. rathonis; chiefly attributed due to production of organic acids like carboxylic acid, ethanedioic acid, glyoxalic acid, malic acid, hydroxy acid and ketobutyric acid (Reyes et al., 2007). In recent decades, interest in endophytic microorganisms has been increased, as they have important role in sustainable agriculture. Knowing and understanding the negative impact of artificial fertilizers in agriculture, novel approaches such as the application of endophytic bacteria as biofertilizer which are associated with plants, may help to increase productivity and improve plant health.

\section{Materials and Methods}

Plant Growth Promotional (PGP) traits for isolates of endophytic bacteria

Determination of Phosphate
solubilization

\section{Phosphate solubilization index (PSI)}

"Qualitative assay for P solubilization of plant associated endophytic bacteria was done by streaking of pure culture on NBRIP medium containg plates (National Botanical Research Institute's Phosphate growth) (Arora 2007). “ Appearence of clear halo zone around bacterial colony after 5-7 days incubation period at $28 \pm 2^{\circ} \mathrm{C}$ was indicated positive for $\mathrm{P}$ solubilization (Nautiyal 1999). Following formula was used to calculate Phosphate solubilization index (PSI):

PSI Index $=\mathrm{A} / \mathrm{B}$

$A=$ Total diameter (colony + halo zone)

$\mathrm{B}=$ Diameter of colony.
Further quantitative phosphate solubilization was performed with promising P solubilizers with presence of clear halo zone around bacterial growth in plate assay method.

\section{Quantitative estimation}

Pikovaskaya's broth $(100 \mathrm{ml})$ and $0.1 \mathrm{~g}_{2} \mathrm{O}_{5}$ as tri-calcium phosphate (TCP) was added in $250 \mathrm{ml}$ conical flask as an inorganic phosphate substrate and the flasks containing broth were autoclaved at $121^{\circ} \mathrm{C}$ for $15 \mathrm{~min}$. The broth was inoculated with $1 \mathrm{ml}$ of overnight grown pure culture suspension and incubation was done at $28 \pm 2^{\circ} \mathrm{C}$ for 15 days. Equal ratio of ammonium molybdate and ammonium vandate was added to culture supernatant and incubated for 25 minutes, development of yellow colour indicated phosphate solubilizing activity. Intensity of the yellow colour of solution was measured spectroscopically (Elico UV-VIS spectrophotometer) at $420 \mathrm{~nm}$ for quantitative estimation (Jackson, 1973).

Qualitative and quantitative analysis for Indole acetic acid (IAA) production

IAA production in different isolates of endophytes were detected (Gordon and Weber 1951) by inoculating pure bacterial culture in $10 \mathrm{ml}$ Luria Bertanni broth with or without tryptophan $(0.01 \%$ L-Trp) and incubation was done at $28-30^{\circ} \mathrm{C}$ for $3-6$ days. Presence of pink colour showed production of IAA which was indicative of positive test. Quantative estimation was done for IAA $\left(\mu \mathrm{gml}^{-1}\right)$ by addition of $2 \mathrm{ml}$ of Salkowski's reagent $(1 \mathrm{ml}$ of $0.5 \mathrm{~m} \mathrm{FeCl}_{3}$ in $50 \mathrm{ml}$ of $35 \% \mathrm{HClO}_{4}$ ) into culture supernatant $\left(\begin{array}{lll}1 & \mathrm{ml}\end{array}\right)$ alongwith uninoculated broth with Salkowski's reagent as a reference. After $20 \mathrm{~min}$, absorbance of pink colour was measured spectroscopically (Elico UV-VIS spectrophotometer) at $535 \mathrm{~nm}$ and quantification of IAA was done by using standard curve. 
Quantative measurement of Gibberellic acid production

Quantative measurement of gibberellic acid by endophytic bacteria was estimated as per method of Borrow et al., (1995).

\section{Reagents}

\section{Zinc acetate solution}

Zinc acetate $(21.9 \mathrm{~g})$ was added into $80 \mathrm{ml}$ of distilled water and $1 \mathrm{ml}$ of glacial acetic acid to make the volume upto $100 \mathrm{ml}$ with distilled water.

\section{Potassium ferrocyanide solution}

Potassium ferrocyanide (10.6g) was mixed in $100 \mathrm{ml}$ distilled water. Cultures inoculated in their relevant broth containing tubes and incubation was done at $37^{\circ} \mathrm{C}$ for seven days. After end of incubation period, cultures were centrifuged for $10 \mathrm{~min}$ at $8000 \mathrm{rpm}$. After centrifugation two $\mathrm{ml}$ of zinc acetate solution was added into fifteen $\mathrm{ml}$ of the culture supernatant. After two minutes, $2 \mathrm{ml}$ of potassium ferrocyanide solution was added and again centrifuged for $10 \mathrm{~min}$ at $8000 \mathrm{rpm}$. Equal volume of supernatant $(5 \mathrm{ml})$ was added to $30 \%$ hydrochloric acid $(5 \mathrm{ml})$ and the test tube was incubated at $27^{\circ} \mathrm{C}$ for $1 \mathrm{hr} 15 \mathrm{~min}$. HCL $(5 \%)$ was used as a blank. UV-VIS spectrophotometer was used to measure the absorbance at $254 \mathrm{~nm}$. Gibberellic acid solution of known strength was used to prepare standard curve to quantify the gibberellic acid produced by the cultures and expressed as $\mu \mathrm{gml}^{-1}$ broth.

\section{Determination of ACC deaminase production}

Qualitative assay was done as per method of Govindasamy et al., (2008). Plates containing Dworkin's and Foster (DF) minimal medium with ACC as a sole nitrogen source were streaked with pure culture of endophytic isolates and bacterial growth was observed (Dworkin and Foster, 1958). Incubation was done for 3-4 days at $28 \pm 1^{\circ} \mathrm{C}$.

\section{Quantitative estimation}

Liquid DF minimal medium with $\left(\mathrm{NH}_{4}\right)_{2} \mathrm{SO}_{4}$, with ACC (sigma, Ltd) and without ACC was used to culture endophytic isolates individually. Growth of bacterial isolates in different media was measured at $600 \mathrm{~nm}$ by using UV-VIS Spectrophotometer (Shahzad et al., 2010).

\section{Results and Discussion}

Phosphorus is the key element in the nutrition of plants, next to nitrogen $(\mathrm{N})$. It plays an important role in virtually all major metabolic processes in plant including photosynthesis, energy transfer, signal transduction, macromolecular biosynthesis, respiration and nitrogen fixation in legumes. For qualitative P- solubilization, all the 167 isolates were tested on NBRIP medium amended with $0.5 \%$ tri calcium phosphate (TCP) as inorganic source of phosphorus. 37 isolates from root were positive for P- solubilization on NBRIP medium. Phosphate solubilization index (PSI) of endophytic bacterial isolates was ranged from 1.25 to 2.22 . Out of 37 roots non rhizobial endophytic isolates $32 \%$ were shown high PSI from root. Highest $P$ solubilization index was recorded with RBR 164 (2.22) followed by LCRE9 (2.15) isolates. Our results are in accordance with Liu et al., (2017) who reported out of 28 isolates of endophytic bacteria from tomato rhizosphere, 24 were able to form halo yellow zone on Pikovaskaya's and NBRIP medium. Kailasan and Vamanrao (2015) reported 23 isolates of 134 showed solubilization index $\geq 1$. PSB isolates showed maximum amount of Psolubilization at $12^{\text {th }}$ days and few at 15 th day 
and varied from 2.70 to $20.60 \mathrm{mg} 100 \mathrm{ml}^{-1}$. Significantly high P-solubilization was recorded in root isolate RBR20 (20.60 $\mathrm{mg} 100 \mathrm{ml}^{-1}$ ) followed by RBR164 (19.80 mg $100 \mathrm{ml}^{-1}$ ) of chickpea (Fig. 1 and Table 1).

Production of phytohormone (IAA) is an important mechanism of plant growth promotion by endophytic bacteria. This hormone promotes the growth of roots. Of 37 root endophytic bacterial isolates $59.37 \%$, $8.10 \%$ and $32.43 \%$ were found to be low, medium and high producer in the presence of tryptophan (Fig. 2). IAA production in root non rhizobial endophytic bacterial isolates

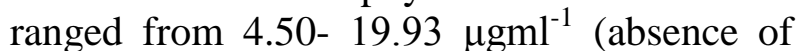
tryptophan) and 21.0-39.60 $\mathrm{ggml}^{-1}$ (presence of tryptophan). In the presence of tryptophan, the isolate LCRE 9 produced the maximum amount of IAA $\left(39.60 \mu \mathrm{gml}^{-1}\right)$ whereas in the absence of tryptophan the isolate RBR164 produced the maximum amount of IAA (19.93 $\mu \mathrm{gml}^{-1}$ ) as given in Table 2. Our results are in close agreement with Priyanka and Leelawati (2015) where of 8 non rhizobial endophytic bacteria from chickpea nodules. In 4 isolates IAA varied from $6.33 \mu \mathrm{g} \mathrm{ml}^{-1}$ to $10.04 \mu \mathrm{g} \mathrm{ml}^{-}$ ${ }^{1}$ in the presence of tryptophan. Our results are also in harmony with the finding of Zaghloul et al., (2016) where of 55 non rhizobial endophytic bacterial isolates 12 produced $>25$ IAA in the presence of tryptophan with maximum amount by the isolate RN62 (92.52 $\mu / \mathrm{ml}$ ) Endophytic bacteria have many beneficial effects on their host plant growth by producing phytohormones similar to that of plant growth promoting rhizobacteria (PGPR). Gibberellic acid (GA) is an important plant growth promoter associated with several plant growth and development processes, such as seed germination, stem elongation, flowering and fruit development. Of 37 root non rhizobial endophytic bacterial isolates $16.21 \%$, $51.35 \%$ and $32.43 \%$ and 38 from were found to be low, medium and high producer of GA, respectively (Fig. 3). Twelve endophytic bacterial isolates viz. RBR17, RBR 19, RBR20, RBR 40, RBR 127, RBR 136, RBR 146, RBR 155, RBR 164, RBR 167, LCRE 8 and LCRE 9 were tended to produce high amount of GA in the range of 59.90 to 112.15 $\mu \mathrm{gml}^{-1}$. High amount of GA production was observed in RBR19, RBR127, RBR136, and RBR164 (112.15 $\left.\mu \mathrm{gml}^{-1}\right)$ procured from wild species of chickpea. Our results are well coherent with Asaf et al., (2017) who isolated 5 bacterial endophytes LK11 (Sphingomonas sp. LK11), TP5 (Bacillus subtilis), MPB5.3 (B. subtilis subsp. Subtilis), S9 (B. subtilis subsp. Subtilis), and TP1 (Serratia marcescens) from arid land-dwelling plants. Enhancement in soybean plants (155.43-146.94 ng/g D.W.) was recorded with gibberellin production endophyte-inoculated as compared to control (113.76 ng/g D.W.).

All 37 endophytic bacterial isolates were subjected for their ACC deaminase production on Dworkin and Foster's minimal medium. The ability of isolates to utilize ACC as a source of $\mathrm{N}$ was assessed on the basis of bacterial growth on plates containing substrate ACC and $\left(\mathrm{NH}_{4}\right)_{2} \mathrm{SO}_{4}$. Based on preliminary qualitative test for screening of endophytic bacterial isolates positive for ACC deaminase, 14 isolates were further assessed on the basis of bacterial growth in liquid medium selected for their ability to utilize ACC as a sole source of $\mathrm{N}$ in terms of optical density (OD at 600). Higher growth of endophytic bacterial isolates was observed in DF broth supplemented with ACC (OD ranged 0.356 to 0.9985) as compared to DF broth supplemented with $(\mathrm{NH} 4)_{2} \mathrm{SO}_{4}$ (OD ranged 0.2954 to 0.5932 ) (Table 6). Data indicated the ability of isolates to use ACC as N source due to the presence of ACC deaminase activity. Little or no growth in DF medium without $\mathrm{ACC}$ or $(\mathrm{NH} 4)_{2} \mathrm{SO}_{4}$ was observed due to the absence of $\mathrm{N}$ source. RBR164 isolate showed highest growth in DF medium with ACC (0.9985) followed by RBR83 (0.9935) (Table 3-6) (Fig. 4). 
Table.1 Qualitative measurement of P-solubilization by root non rhizobial endophytic bacterial isolates of chickpea on NBRIP medium

\begin{tabular}{|c|c|c|c|}
\hline Isolates & Colony Diameter & Colony + Holo Zone Diameter & PSI \\
\hline RBR11 & 0.9 & 1.5 & 1.67 \\
\hline RBR14 & 1.1 & 1.8 & 1.64 \\
\hline RBR17 & 1.1 & 2.1 & 1.91 \\
\hline RBR 19 & 1.1 & 2 & 1.82 \\
\hline RBR20 & 1 & 2.1 & 2.10 \\
\hline RBR25 & 1 & 1.6 & 1.60 \\
\hline RBR27 & 1.2 & 2.1 & 1.75 \\
\hline RBR31 & 1.3 & 2.2 & 1.69 \\
\hline RBR34 & 1 & 1.7 & 1.70 \\
\hline RBR38 & 0.8 & 1.4 & 1.75 \\
\hline RBR40 & 1 & 2 & 2.00 \\
\hline RBR49 & 0.9 & 1.6 & 1.78 \\
\hline RBR57 & 0.8 & 1 & 1.25 \\
\hline RBR61 & 0.9 & 1.6 & 1.78 \\
\hline RBR63 & 0.9 & 1.5 & 1.67 \\
\hline RBR72 & 1 & 1.7 & 1.70 \\
\hline RBR75 & 1.2 & 1.6 & 1.33 \\
\hline RBR80 & 1.3 & 1.7 & 1.31 \\
\hline RBR83 & 1 & 1.5 & 1.50 \\
\hline RBR89 & 1 & 1.6 & 1.60 \\
\hline RBR112 & 1 & 1.5 & 1.50 \\
\hline RBR116 & 1.1 & 1.8 & 1.64 \\
\hline RBR119 & 0.8 & 1.3 & 1.63 \\
\hline RBR121 & 0.7 & 1.1 & 1.57 \\
\hline RBR127 & 0.8 & 1.5 & 1.87 \\
\hline RBR128 & 1.1 & 1.9 & 1.73 \\
\hline RBR136 & 1 & 2.0 & 2.0 \\
\hline RBR139 & 1.2 & 2 & 1.67 \\
\hline RBR144 & 1.2 & 1.6 & 1.33 \\
\hline RBR145 & 0.9 & 1.6 & 1.78 \\
\hline RBR146 & 1 & 2 & 2.00 \\
\hline RBR155 & 1.1 & 2.1 & 1.91 \\
\hline RBR164 & 0.9 & 2 & 2.22 \\
\hline RBR165 & 1.1 & 1.7 & 1.55 \\
\hline RBR167 & 0.9 & 1.9 & 2.11 \\
\hline LCRE8 & 1.1 & 2.1 & 1.91 \\
\hline LCRE9 & 1.3 & 2.8 & 2.15 \\
\hline LGR33 & 1.2 & 1.9 & 1.58 \\
\hline RB1 & 0.7 & 1.3 & 1.86 \\
\hline
\end{tabular}


Table.2 Quantitative measurement of P-solubilization by root non rhizobial endophytic bacterial isolates in Pikovaskaya's broth at a different interval of time

\begin{tabular}{|c|c|c|c|c|c|}
\hline \multirow[t]{3}{*}{ Isolates } & \multicolumn{5}{|c|}{ P-solubilization $\left(\mathrm{mg} 100 \mathrm{ml}^{-1}\right)$} \\
\hline & \multicolumn{5}{|c|}{ Incubation period (days) } \\
\hline & $3^{\text {rd }}$ & $6^{\text {th }}$ & $9^{\text {th }}$ & $12^{\text {th }}$ & $15^{\text {th }}$ \\
\hline RBR11 & 1.1 & 2.5 & 4.4 & 4.5 & 5.2 \\
\hline RBR14 & 2.2 & 4.8 & 5.1 & 6.1 & 5.76 \\
\hline RBR17 & 1.0 & 2.2 & 15.3 & 16.8 & 7.8 \\
\hline RBR 19 & 1.3 & 2.9 & 5.3 & 17.6 & 6.4 \\
\hline RBR20 & 8.9 & 19.3 & 19.9 & 20.6 & 18.0 \\
\hline RBR25 & 0.3 & 1.0 & 4.8 & 4.9 & 3.9 \\
\hline RBR27 & 3.0 & 4.4 & 10.1 & 11.1 & 12.8 \\
\hline RBR31 & 0.3 & 2.6 & 4.4 & 6.0 & 5.7 \\
\hline RBR34 & 0.5 & 5.9 & 8.4 & 10.5 & 2.8 \\
\hline RBR38 & 4.5 & 6.0 & 11.0 & 12.1 & 4.7 \\
\hline RBR40 & 1.2 & 7.4 & 8.8 & 12.3 & 6.9 \\
\hline RBR49 & 3.7 & 5.1 & 13.2 & 13.4 & 8.3 \\
\hline RBR57 & 0.3 & 2.6 & 2.4 & 2.7 & 2.6 \\
\hline RBR61 & 0.3 & 1.4 & 6.2 & 8.1 & 9.8 \\
\hline RBR63 & 6.3 & 9.4 & 9.6 & 10.1 & 6.4 \\
\hline RBR72 & 0.3 & 5.7 & 5.7 & 7.7 & 6.5 \\
\hline RBR75 & 4.0 & 4.4 & 6.7 & 9.9 & 3.3 \\
\hline RBR80 & 1.0 & 5.2 & 5.9 & 10.8 & 5.1 \\
\hline RBR83 & 1.6 & 3.1 & 10.0 & 10.7 & 6.2 \\
\hline RBR89 & 2.9 & 4.8 & 10.0 & 10.7 & 5.5 \\
\hline RBR112 & 4.6 & 7.4 & 10.3 & 11.3 & 5.6 \\
\hline RBR116 & 0.4 & 1.4 & 4.4 & 10.6 & 3.1 \\
\hline RBR119 & 1.6 & 1.7 & 2.9 & 3.8 & 7.3 \\
\hline RBR121 & 1.7 & 4.8 & 4.9 & 5.8 & 2.1 \\
\hline RBR127 & 0.3 & 2.1 & 5.4 & 12.3 & 6.9 \\
\hline RBR128 & 4.4 & 5.1 & 5.7 & 10.6 & 4.9 \\
\hline RBR136 & 4.8 & 4.9 & 13.8 & 15.8 & 5.0 \\
\hline RBR139 & 4.3 & 5.0 & 8.6 & 10.9 & 8.8 \\
\hline RBR144 & 0.3 & 2.2 & 2.4 & 4.5 & 6.9 \\
\hline RBR145 & 3.0 & 4.5 & 5.5 & 6.2 & 5.0 \\
\hline RBR146 & 9.5 & 13.3 & 14.7 & 15.4 & 8.0 \\
\hline RBR155 & 3.5 & 5.0 & 12.7 & 9.0 & 6.4 \\
\hline RBR164 & 5.3 & 5.6 & 16.9 & 19.8 & 7.5 \\
\hline RBR165 & 4.9 & 7.2 & 8.1 & 8.8 & 3.7 \\
\hline RBR167 & 5.0 & 6.4 & 13.0 & 13.6 & 17.5 \\
\hline LCRE8 & 6.57 & 14.19 & 15.69 & 16.07 & 15.44 \\
\hline LCRE9 & 2.39 & 4.42 & 9.76 & 12.86 & 3.86 \\
\hline LGR33 & 2.6 & 4.1 & 4.9 & 8.7 & 3.4 \\
\hline RB1 & 4.5 & 7.32 & 7.31 & 10.19 & 7.75 \\
\hline CD@ @ $5 \%$ & 0.35 & 0.39 & 0.15 & 0.39 & 0.45 \\
\hline
\end{tabular}


Table.3 Quantitative measurement of IAA production by root non rhizobial endophytic bacterial isolates of chickpea

\begin{tabular}{|c|c|c|}
\hline Isolates & $\begin{array}{l}\text { Without Tryptophan } \\
\left(6^{\text {th }} \text { Day }\right)(\mu / \mathrm{ml})\end{array}$ & $\begin{array}{l}\text { With Tryptophan } \\
\left(6^{\text {th }} \text { Day }\right)(\mu \mathrm{g} / \mathrm{ml})\end{array}$ \\
\hline RBR11 & 7.98 & 21.70 \\
\hline RBR14 & 8.17 & 21.37 \\
\hline RBR17 & 12.51 & 30.75 \\
\hline RBR 19 & 12.23 & 31.35 \\
\hline RBR20 & 17.83 & 32.81 \\
\hline RBR25 & 8.14 & 24.10 \\
\hline RBR27 & 9.19 & 21.00 \\
\hline RBR31 & 9.70 & 21.71 \\
\hline RBR34 & 9.38 & 22.71 \\
\hline RBR38 & 9.98 & 22.64 \\
\hline RBR40 & 14.70 & 34.93 \\
\hline RBR49 & 7.57 & 23.24 \\
\hline RBR57 & 5.08 & 27.08 \\
\hline RBR61 & 7.71 & 21.62 \\
\hline RBR63 & 8.21 & 24.92 \\
\hline RBR72 & 7.39 & 24.50 \\
\hline RBR75 & 5.40 & 23.71 \\
\hline RBR80 & 4.50 & 23.17 \\
\hline RBR83 & 7.42 & 22.04 \\
\hline RBR89 & 9.07 & 21.35 \\
\hline RBR112 & 8.82 & 21.25 \\
\hline RBR116 & 7.88 & 21.10 \\
\hline RBR119 & 9.37 & 21.43 \\
\hline RBR121 & 7.60 & 22.82 \\
\hline RBR127 & 14.70 & 32.84 \\
\hline RBR128 & 8.01 & 22.90 \\
\hline RBR136 & 11.98 & 33.21 \\
\hline RBR139 & 9.38 & 22.61 \\
\hline RBR144 & 9.35 & 24.08 \\
\hline RBR145 & 6.79 & 27.66 \\
\hline RBR146 & 14.13 & 31.68 \\
\hline RBR155 & 14.30 & 39.00 \\
\hline RBR164 & 19.93 & 39.31 \\
\hline RBR165 & 10.37 & 21.80 \\
\hline RBR167 & 13.27 & 37.20 \\
\hline LCRE8 & 14.28 & 37.16 \\
\hline LCRE9 & 16.10 & 39.60 \\
\hline LGR33 & 15.28 & 32.45 \\
\hline RB1 & 14.23 & 35.72 \\
\hline CD@5\% & 0.02 & 0.08 \\
\hline
\end{tabular}


Table.4 Quantitative estimation of gibberellic acid by root non rhizobial endophytic bacterial isolates of chickpea

\begin{tabular}{|c|c|}
\hline Isolates & $\mathrm{GA}_{3}\left(\mu \mathrm{gl}^{-1}\right)$ \\
\hline RBR11 & 85.39 \\
\hline RBR14 & 96.63 \\
\hline RBR17 & 101.56 \\
\hline RBR 19 & 112.15 \\
\hline RBR20 & 111.38 \\
\hline RBR25 & 95.48 \\
\hline RBR27 & 89.62 \\
\hline RBR31 & 95.25 \\
\hline RBR34 & 91.76 \\
\hline RBR38 & 91.28 \\
\hline RBR40 & 108.53 \\
\hline RBR49 & 100.29 \\
\hline RBR57 & 92.15 \\
\hline RBR61 & 94.15 \\
\hline RBR63 & 83.73 \\
\hline RBR72 & 97.15 \\
\hline RBR75 & 98.13 \\
\hline RBR80 & 86.00 \\
\hline RBR83 & 92.15 \\
\hline RBR89 & 96.83 \\
\hline RBR112 & 93.60 \\
\hline RBR116 & 59.90 \\
\hline RBR119 & 92.15 \\
\hline RBR121 & 96.01 \\
\hline RBR127 & 112.15 \\
\hline RBR128 & 92.33 \\
\hline RBR136 & 112.15 \\
\hline RBR139 & 94.21 \\
\hline RBR144 & 95.33 \\
\hline RBR145 & 99.59 \\
\hline RBR146 & 101.83 \\
\hline RBR155 & 108.45 \\
\hline RBR164 & 112.15 \\
\hline RBR165 & 92.15 \\
\hline RBR167 & 108.64 \\
\hline LCRE8 & 104.64 \\
\hline LCRE9 & 105.51 \\
\hline RB1 & 80.65 \\
\hline CD 53 & 11.91 \\
\hline & 0.41 \\
\hline
\end{tabular}


Table.5 Qualitative ACC deaminase production by non rhizobial endophytic Bacteria of chickpea

\begin{tabular}{|c|c|}
\hline Broth & $\begin{array}{c}\text { ACC deaminase positive non rhizobial endophytic bacterial } \\
\text { isolates }\end{array}$ \\
\hline DF & $\begin{array}{l}\text { RBR12, RBR14,RBR61, RBR72, RBR89, RBR119, RBR121, } \\
\text { RBR127, RBR 139, RBR } 146\end{array}$ \\
\hline $\mathrm{DF}+\left(\mathrm{NH}_{4}\right) \mathrm{SO}_{4}$ & $\begin{array}{l}\text { RBR12, RBR17, RBR19, RBR20, RBR34, RBR40, RBR72, } \\
\text { RBR80, RBR83, RBR89, RBR119, RBR121, RBR127, } \\
\text { RBR136, RBR139, RBR146, RBR155 \& LCRE8 }\end{array}$ \\
\hline $\mathrm{DF}+\mathrm{ACC}$ & $\begin{array}{l}\text { RBR12, RBR17, RBR19, RBR20, RBR25, RBR34, RBR40, } \\
\text { RBR72, RBR80, RBR83, RBR89, RBR119, RBR121, } \\
\text { RBR127, RBR136, RBR139, RBR144, RBR146, RBR155, } \\
\text { RBR164, RBR165 \& LCRE8 }\end{array}$ \\
\hline
\end{tabular}

Table.6 Quantative ACC deaminase production by non rhizobial endophytic bacteria from chickpea in DF minimal medium

\begin{tabular}{|c|c|c|}
\hline Isolates & $\mathrm{DF}+\mathrm{ACC}$ & $\mathrm{DF}+\left(\mathrm{NH}_{4}\right) \mathrm{SO}_{4}$ \\
\hline RBR17 & 0.356 & 0.2954 \\
\hline RBR 19 & 0.8743 & 0.3875 \\
\hline RBR20 & 0.8530 & 0.5830 \\
\hline RBR25 & 0.8267 & 0.3742 \\
\hline RBR34 & 0.6743 & 0.4891 \\
\hline RBR40 & 0.8649 & 0.2965 \\
\hline RBR80 & 0.7492 & 0.3502 \\
\hline RBR83 & 0.9935 & 0.4683 \\
\hline RBR136 & 0.4162 & 0.2957 \\
\hline RBR144 & 0.998 & 0.5932 \\
\hline RBR155 & 0.8697 & 0.4700 \\
\hline RBR164 & 0.9985 & 0.3520 \\
\hline RBR165 & 0.7851 & 0.5831 \\
\hline LCRE8 & 0.7821 & 0.2843 \\
\hline RB1 & 0.9225 & 0.5932 \\
\hline
\end{tabular}


Fig.1 Phosphate solubilization Index (\% PSI) of non rhizobial root endophytic Bacteria of chickpea

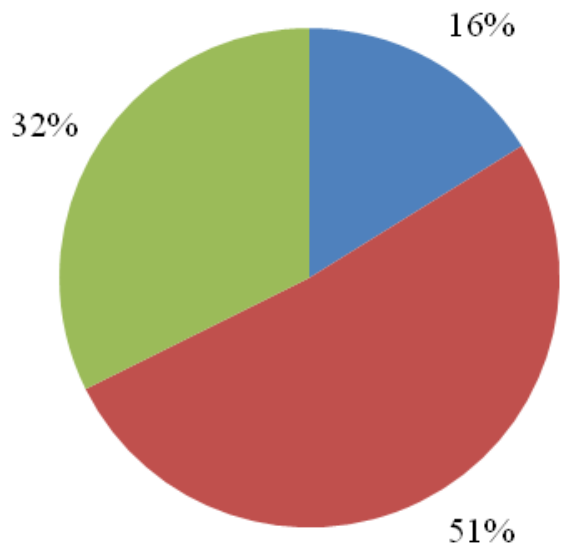

Low PSI (1.2-1.5)

- Medium PSI (1.6-1.8)

High PSI (1.9-2.2)

Fig.2 Indole acetic acid production (with tryptophan) of root non rhizobial root endophytic bacteria of chickpea

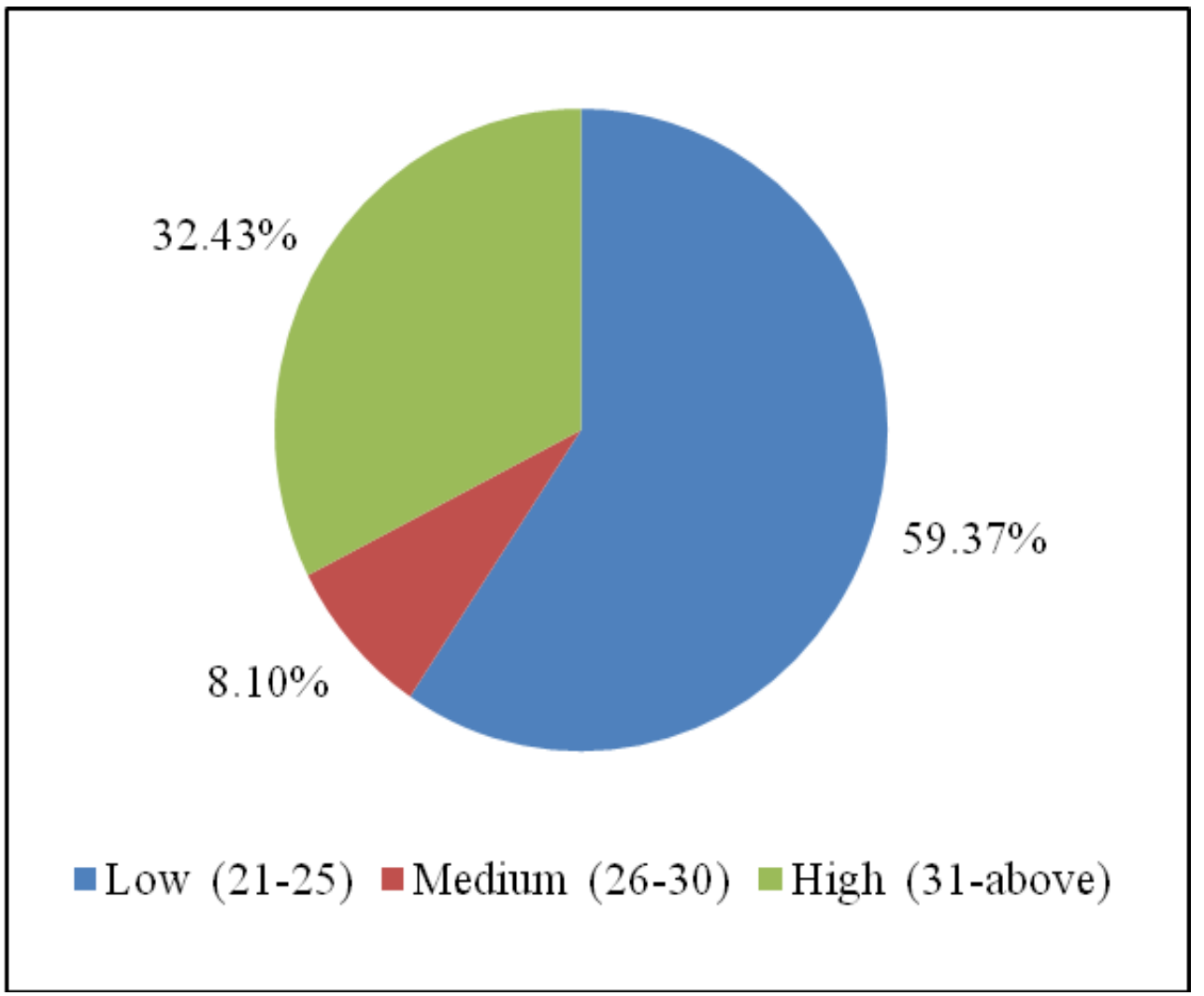


Fig.3 Gibberellic acid production of root non rhizobial root endophytic bacteria of Chickpea in nutrient broth

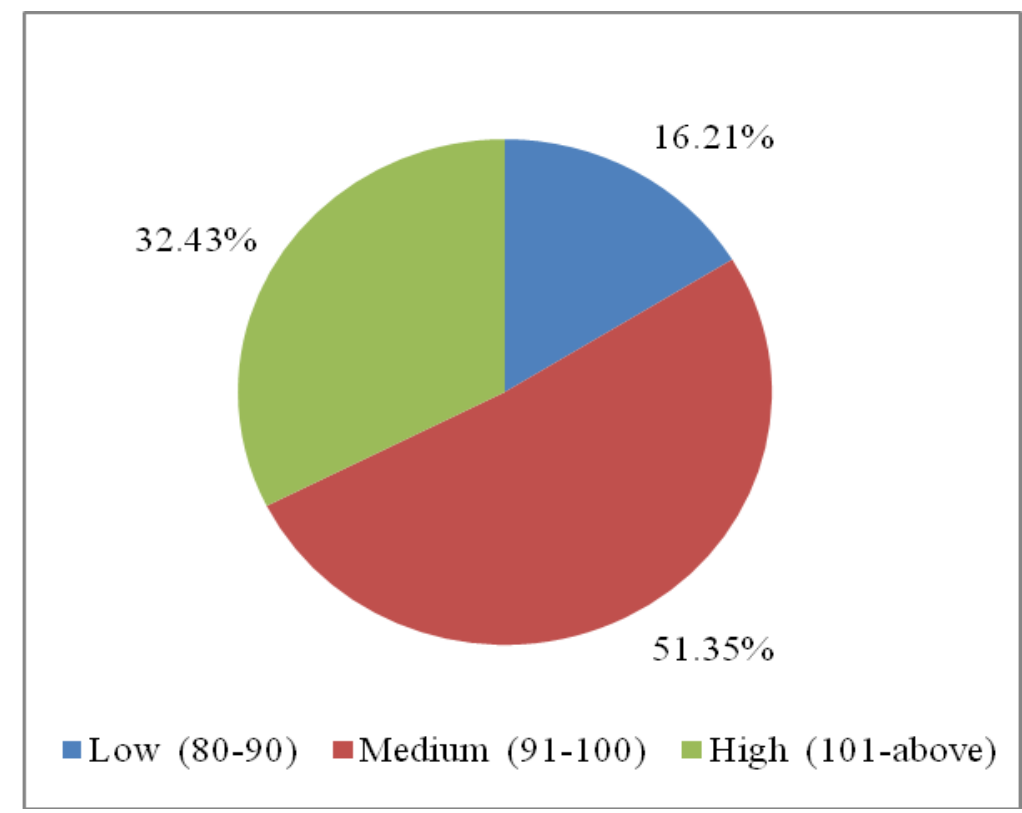

Fig.4 Potential ACC deaminase producers of non rhizobial endophytic root bacteria in DF minimal medium amended with ACC and $\left(\mathrm{NH}_{4}\right)_{2} \mathrm{SO}_{4}$

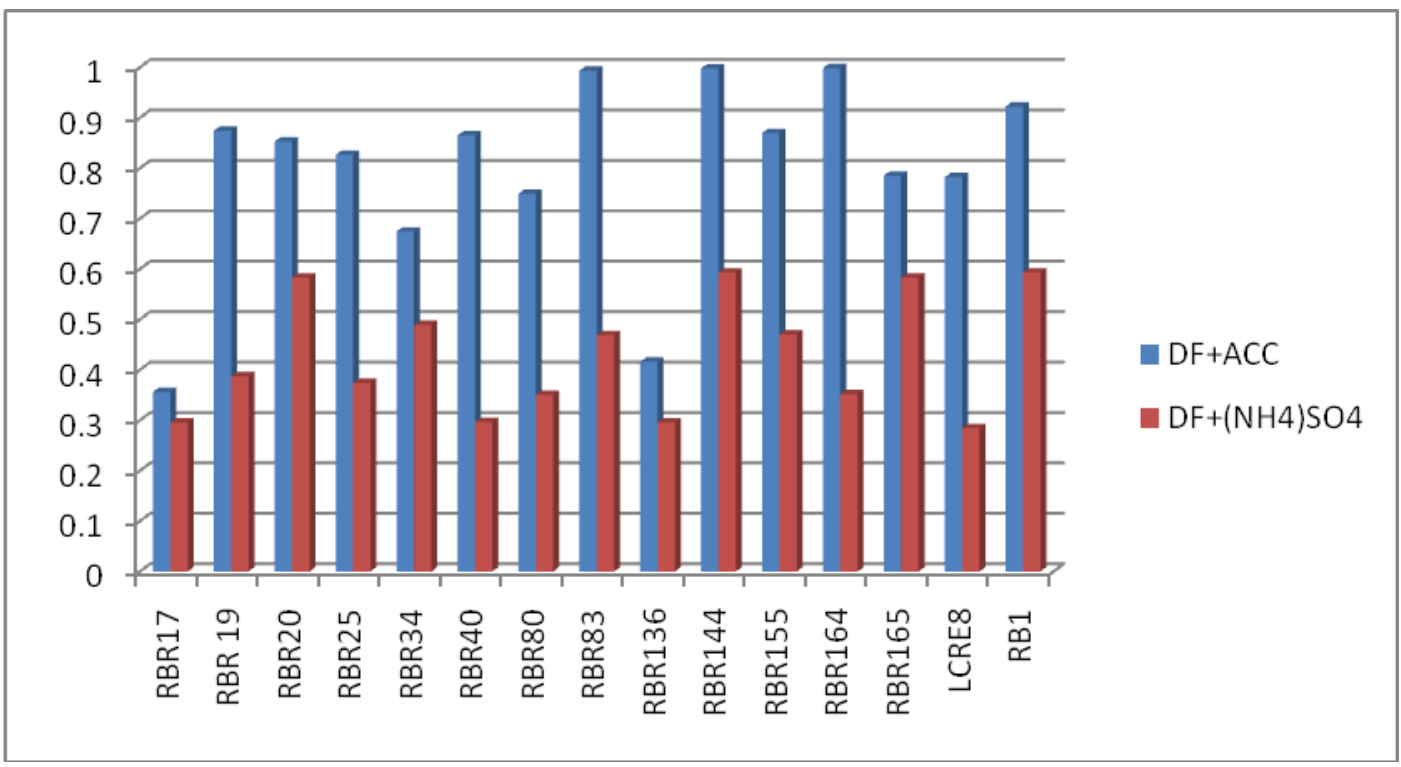

All the 14 isolates utilized ACC as $\mathrm{N}$ source (i.e. positive for ACC-deaminase enzyme activity) but with different degree of efficacy.

Similarly, Subramanian et al., (2015) revealed endophyte Bacillus megaterium LNL6 from root nodules of Lesperdeza sp. and plant endophyte Methylobacterium oryzae CBMB20 from rice leaves as ACC deaminase producers. Our result are supported by Ghose et al., (2015) who isolated three IAA and ACC deaminase producing Enterobacter spp. 
(A3CK, A7CK and $\mathrm{A} 27 \mathrm{CK}$ ) from the root nodule of legume $A$. precatorius $\mathrm{L}$.

\section{Acknowledgement}

The authors are thankful to Punjab Agricultural University, Ludhiana, India for providing necessary facilities to conduct the present study.

\section{References}

Akhtar, M. and Siddiqui, Z. (2009). Effects of phosphate solubilizing microorganisms and Rhizobium sp. on the growth, nodulation, yield and root-rot disease complex of chickpea under field condition. Afiican Journal of Biotechnology. 8(15): 3489-3496.

Arora, D. K. (2007). Microbial Identification modules for some agriculturally important microorganisms. Pp 97-107. National Burea of Agriculturally Important microorganisms (NBAIM), Mau, U.P.

Asaf, S., Khan, M. A., Khan, A. L., Waqas, M., Shahzad, R., Kim, A. Y., Kang, S. M. and Lee, I. J. (2017). Bacterial endophytes from arid land plants regulate endogenous hormone content and promote growth in crop plants: an example of Sphingomonas sp. and Serratia marcescens. Journal of Plant Interaction. 12 (1): 31-38

Bhattacharyya, P.N., and Jha, D. K. (2012). Plant growth-promoting rhizobacteria (PGPR): Emergence in agriculture. World Journal of Microbiology and Biotechnology. 28: 1327-1350.

Borrow, A., Brian, P. W., Chester, V. E., Curtis, P. J., Hemming, H. G., Henhen, Jefferys, E. G., Lloyyd, P. B., Nixon, I. S., Norris, G. L. F. and Radley, M. (1995). Gibberellic acid, a metabolic product of the fungus Gibberella fujikuroi: some observations on its production and isolation. Jounal of Science Food Agricultural. 6: 340-348.

Dworkin, M. and Foster, J. (1958) Experiments with some microorganisms which utilize ethane and hydrogen. $J$ Bacteriol 75: 592-601.

Ghosh, P. K., De, T. K. and Maiti, T. K. (2015). Production and metabolism of Indole Acetic Acid in root nodules and symbiont (Rhizobium undicola) isolated from root nodule of aquatic medicinal legume Neptunia oleracea Lour. Journal of Botony. 2015: 1-11.

Gordon, S. and Weber, R. P. (1951). The colorimetric estimation of IAA. $P l$ Physiol 26: 192-199.

Govindasamy, V., kumar, M., Gaikwad, K. and Annapurna, K. (2008). Isolation and Characterization of ACC Deaminase Gene from Two Plant GrowthPromoting Rhizobacteria. Current Microbiology 57(4): 312-317.

Jackson, M. L. (1973). Estimation of phosphorus content Soil chemical analysis. Pp 521. Printer Hall New Delhi (India)

Kailasan N. S., and Vamanrao V. K. (2015) Isolation and characterization of Ralstonia pickettii - A novel phosphate solubilizing bacterium from pomegranate rhizosphere from western India. Int J Life Sci Biotechnol Pharm Res 4: 1-9.

Liu K., Newman M., McInroy A. J., ChiaHui $\mathrm{Hu}$, and Kloepper W. J. (2017) Selection and Assessment of Plant Growth-Promoting Rhizobacteria for Biological Control of Multiple Plant Diseases. Phytopathol 107(8): 928-936.

Nautiyal, C. S. (1999). An efficient microbiology growth medium for screening phosphate solubilising microorganisms. FEMS Microbiology Letters 170: 265-270.

Priyanka, and Leelawati, (2015) Assessment of endophytic bacteria for growth 
promotion in chickpea. Indian Journal of Science Research and Technology. 3(4): 25-29.

Reyes, I. A., Valery, and Valduz, Z. (2007). Phosphate solubilizing microorganisms isolated from rhizospheric and bulk soils of colonizer plants at an abandoned rock phosphate mine. In: E. Velázquez and C. Rodríguez-Barrueco (eds.), First International Meeting on Microbial Phosphate Solubilization. pp. 69-75.

Ryan, R. P., Germaine, K., Franks, A., Ryan, D. J. and Dowling, D. N. (2008). Bacterial endophytes: recent developments and applications. FEMS Microbiology Letters. 278: 1-9.

Shahzad, S. M., Khalid, A., Arshad, M. and Rehman, K. U. (2010). Screening rhizobacteria containing ACCdeaminase for growth promotion of chickpea seedlings under axenic conditions. Soil Environment. 29(1): 38 $-46$.

Subramanian, P., Kim, K., Krishnamoorthy, R., Sundaram, S. and Sa, T. (2015). Endophytic bacteria improve nodule function and plant nitrogen in soybean on co-inoculation with Bradyrhizobium japonicum MN110. Plant Growth Regulation. 76: 327-332.

Wakelin, S. A., Warren, R. A., Harvey, P. R. and Ryder, M. H. (2004). Phosphate solubilization by Penicillium spp. closely associated with wheat roots. Biology and Fertility of Soils. 40: 36-43

Zaghloul, R. A., Abou-Aly, H. E., Tewfike, T. A. and Ashry, N. M. (2016). Isolation and characterization of endophytic bacteria isolated from legumes and nonlegumes plants in Egypt. Journal of Pure and Applied Microbiology. 10(1): 277-290.

\section{How to cite this article:}

Deepika Chhabra and Poonam Sharma. 2019. Tapping of Root Non-Rhizobial Endophytic Bacteria from Chickpea Plant Tissues for Multifunctional Traits. Int.J.Curr.Microbiol.App.Sci. 8(02): 3350-3362. doi: https://doi.org/10.20546/ijcmas.2019.802.390 